centage of that hitherto believed necessary, namely, of the order of $5 \times 10^{7}$ volts as compared with Wilson's $1 \times 10^{9}$ to $6 \times 10^{9}$ volts. The energy involved in a flash is of the order of $250 \mathrm{kwh}$. , while the average charge is of the order of 50 coulombs, or 50 per cent greater than had been previously accepted. About one third of this charge is probably neutralized in the intervening space charge.

Available statistical data show that thunderstorms all over the world have similar flash time characteristics and numbers of strokes per flash. Strokes to the Empire State Building, New York, were found to be similar in overall duration to those occurring in ordinary country, due allowance being made for the duration of the initial continuing stroke. The currents in the flashes, however, were greater than those in flashes to normal country. Evidence purporting to suggest that storms in temperate regions vary in the number of strokes per flash was found to be inconclusive, and it is suggested that the later strokes of a flash are less intense than the earlier ones. These successive strokes are initiated by streamers from the original stroke to other cloud centres, and it is thought that strokes to transmission line conductors which do not cause flashover are unlikely to be followed by subsequent strokes.

Support was obtained for the suggestion that the wave forms of atmospherics are due to successive reflexions from the ionosphere and not to current pulsations in the lightning channel.

Negative flashes to earth are more frequent than positive flashes, the ratio being considerably smaller in temperate than in tropical regions. The polarities of direct strokes to transmission lines are unobtainable from magnetic-link observations on transmission towers. A higher proportion of positive currents has been observed by the cathode ray oscillograph as compared with negative currents.

Norinder's values for individual stroke currents are shown to be in error, an important selective principle having been neglected when comparing these with magnetic-link data.

\section{SOUTH AFRICAN PREHISTORY}

A

NUMBER of interesting articles are contained in the Transactions of the Rhodesia Scientific Association, 37 (April, 1941). It is good to learn that the study of the rock-shelter paintings of Southern Rhodesia continues, and the Hon. L. Cripps speaks of thousands of sites of which he has visited and made copies of paintings at some six hundred. This is no mean work, and his little paper, scientifically written so far as it goes, is, one hopes, only the precursor of a larger work. The author has continued to study the superpositions of the different coloured paintings (though making no mention of any changes of style or subject-matter) and by th se means makes out an age-colour sequence not materially differing from that which I was able to suggest in 1928. Further, he considers that the paintings were connected with the burial of the dead, and that the present-day natives are the descendants of the artists. I venture to suggest that some at least of the paintings go back to a very remote period, and that much migration into the country has taken place since they were made. It is always difficult to deny continuity of blood in any given instance, but I doubt whether there is any general direct descent from the earliest painters to the modern inhabitants. Indeed, I am not even sure that the painters in claret were themselves the direct descendants of those who used the earlier colours. May I perhaps remind Mr. Cripps that the problem of dating the paintings will surely involve excavations in the sites and that Bambata and Nswatugi seem to point the way and have in fact already helped in this direction?

Mr. K. Radcliffe-Robinson describes a Stone Age industry from the Wedza district, some three hundred yards from the Sabi River on the banks of a tributary. Dolerite is the chief material used. Implements of various types occur, and, if the industry is really homogeneous, the age cannot be very remote, although some handaxe-like types and a possible burin occur. But so does a polished tool! The occurrence of burins in more or less recent levels has been noted by Schofield in Natal, and rough core tools somewhat of a handaxe type are also not unknown. The technique of polishing is not very common, but examples are known from Southern Rhodesia, and farther to the south, for example, there are local specimens in the Museum at Grahamstown. In no case does this technique appear to be very ancient so far as we can determine. At a part of the site a little distant from the main mass of these tools there was found a Rhodesian Stillbay industry of quartz and ironstone, but owing to the lack of any stratigraphy it is, as is so sadly usual in this country, impossible to prove any relative dating of the two industries. This paper, too, shows a scientific attitude to the problems of Rhodesian prehistory; the draw. ings are adequate but might have been better arranged.

Mr. C. Martin describes pottery-making in Nanyikaland, an art which is apparently dying out. As usual in Bantu tribes, pottery-making is woman's work. A good description and some interesting photographs are given.

\section{C. BURKITT}

\section{DRUG PRODUCTION IN THE BRITISH EMPIRE}

TN a paper on "British Empire Drug Production" 1 before the Royal Society of Arts on December 16 (J. Roy. Soc. Arts, 90, 138; 1942), Dr. Maurice Ashby points out that we are normally dependent on imports from overseas for practically the whole of our requirements of crude drugs, and a large proportion of our pre-war imports came from countries outside the Empire, the continent of Europe being our main source of supply of such vital drugs as belladonna, digitalis, henbane and stramonium. Dr. Ashby, after emphasizing the difficulties which might be encountered, owing to the influence of environment and inherent physiological differences, in growing medicinal plants in a new country where the climate or soil conditions might not be quite the same as in its original home, gave an encouraging account of what is being done in Empire countries to meet essential needs.

In Canada the most important development is the introduction of cascara as a crop, but some years will be required before supplies are available from the new plantings. In Australia and New Zealand the two most important items are agar-agar and ergot, and both Australia and New Zealand appear 
hopeful of producing really good-quality agar on a commercial scale.

Large-scale experiments on the artificial production of ergot on rye were undertaken in Australia on behalf of the British Government. New Zealand could probably produce most of the medicinal herbs we formerly imported from Central Europe, but the high cost of labour would make this uneconomic. With regard to India, Burma, Ceylon and Malaya, about 90 per cent of the world's supply of cinchona bark came from Java, which holds a virtual monopoly of the market. Indian production is still largely confined to Bengal and Madras, and has always aimed at satisfying local needs. Cinchona cultivation has been revived in Ceylon in recent years and there has also been experimental work in Malaya and Tanganyika. We have flourishing ipecacuanha industries in Bengal and Malaya but the quantities produced are very small, South America, particularly Brazil, being practically the only source of supply and, as ipecacuanha is a difficult crop to grow and takes some three years to mature, development must be slow. Malaya is also the leading producer of derris root, and strains have been developed with a far higher rotenone content than the original wild material or that produced by other countries.

The citronella oil industry of Ceylon has now assumed added importance, while in India karaya gum is proving a satisfactory substitute for some of the more costly gums like gum tragacanth and gum arabic. The Himalayas offer endless possibilities for belladonna, henbane, etc.

In the Mediterranean area the chief items are liquorice root and squill, particularly in Cyprus and Palestine. From South Africa the chief drug products are Cape aloes and buchu leaves. Cascara production in East Africa has been moderately successful and there has been experimental work on ephedra and on ocimum oils as a source of camphor, but the most striking success has been the pyrethrum industry.

\section{APPOINTMENTS VACANT}

APPLICATIONS are invited for the following appointments on or before the dates mentioned:

ChIEP ASSISTANT To THE AYRShIRE ElectricITy BOARD - The Clerk to the Ayrshire Electricity Board, Greenholm Street, Kilmarnock (endorsed 'Chief Assistant') (March 2).

Senior LeCTURER IN PATHOLOGX, and a JUNIOR LECTURER IN PATHOLOGY-The Secretary, Royal (Dick) Veterinary College, Summerhall, Edinburgh 9 (March 16).

DEMONSTRATOR IN BOTANY at Westfield College, University of London-The Registrar, Westfleld College, at St. Peter's Hall, Oxford, ASSISTANT CHEMISTS, PARTLY FOR LABORATORY AND PARTLY FOR PROCESS PLANT OPERATION, for employment in the East-The National Service, Hanway House, Red Lion Square, London, W.C.1. Conlow CHEMIsT or PHYsicist-The Director of Research, British Pottery Research Association, Queens Road, Penkhull, Stoke-onTrent.

\section{FORTHCOMING EVENTS}

(Meetings marked with an asterisk are open to the public)

\section{Saturday, February 21}

NoRth OF ENGLAND INSTITUTE OF MiNING AND MEChaNiCal ENGINEERS (at Neville Hall, Newcastle-upon-Tyne), at 2 p.m.-Mr. L. C. Maitland: "Mining Timber, Possible Economies and Substitutes".

\section{Monday, February 23}

RoYal College of SURgeons of ENGLAND (at Lincoln's Inn Fields, London, W.C.2), at 2.30 p.m.-Prof. J. Beattie :" "Physical and Chemical Changes in the Blood associated with Shock and Hæmorrhage"

ROYAL GEOGRAPHICAI SOCIETY (at Kensington Gore, London S.W.7), a.t 5 p.m.-Geographical Films.
Tuesday, February 24

ROYAL SocIETY oF ARTS (DOMINIONS AND COLONIES SECTION) (at John Adam Street, Adelphi, London, W.C.2), at 1.45 p.m.-Prof. C. W. Wardlaw: "Banana Research at the Imperial College of

Chadwick PUBLIC LeCTURE (at the Royal Society of Tropical Medicine and Hygiene, 26 Portland Place, London, W.1), at 2.30 p.m.- Mr. Ewart G. Culpin: "Reconstruction after the War, with special reference to the Problems of Town and Country Planning"."

ROYAL COLLEGE OF SURGEONS OF ENGLAND (at Lincoln's Inn . Hæmorrhage".

Institute of Physics (Joint Meeting of the London and Home Counties' Branch and the Royal Photographic Society) (at the Royal Photographic Society, 16 Princes Gate, London, S.W.7), at 5 p.mMr. E. R. Davies: "The Role of Photography in the Detection and Measurement of Radiation".

\section{Wednesday, February 25}

ROYal Societr of ARTs (at John Adam Street, Adelphi, London, W.C.2), at 1.45 p.m.-Mr. James Hogan: "The Post-War Home-its Interior and Equipment". 6: "Pottery, Glass and Plastics".

Coke Oven Managers' Associamion (Joint Meeting with the Institute of Fuel together with the Iron and Steel Institute and the Institution of Gas Engineers) (at the Royal Victoria Station Hotel, Sheffield), at 2.30 p.m.-Mr. J. G. Bennett: "The Future of Coke".

GEological Society of LoNdon (at Burlington House, Piccadilly, London, W.1), at 3 ,p.m.-Dr. K. S. Sandford: "The Geology of

\section{Thursday, February 26}

RoYal InstiTution (at 21 Albemarle Street, London, W.1), at 2.30 p.m. - Rt. Hon. the Earl of Onslow, G.B.E. :" "The Preservation of

\section{Friday, February 27}

Institution of MECHANICAL EngINERRs (at Storey's Gate, London, S.W.1), at 2.30 p.m.-Mr. Hal Gutteridge : "Proneness to Damage of Plant through Enemy Action".

BRITISH INSTITUTION OF RADIO ENGINEERS (MIDLAND SECTION) (at James Watt Memorial Institute, York House, Great Charles Street, Birmingham 3), at, 6 p.m.--Mr. G. Bernard Baker: "Ther-

\section{Saturday, February 28}

RoYal Sanitary Instimute (at the Nuffield Institute of Clinical ROYAL SANITARY INSTITUTE (at the Nuffield Institute of Clinical Research, Oxford), at 10 a.m.-Mr. H. H. Crawley: "The Storage of tion of the Government Evacuation Scheme",

NUTRITION Societr (at the London School of Hygiene and Tropical Medicine, Keppel Street, London, W.C.1), at 10.30 a.m.-Conference on "Food Production and Distribution in relation to Nutritional E. T. Halnan, and Sir John Russell, F.R.S.)

\section{REPORTS and other PUBLICATIONS}

(not included in the monthly Books Supplement)

Great Britain and Ireland

Proceedings of the Royal Society of Edinburgh. Section A (Mathematies and Physical Sciences). Vol. 61, Part 2, No. 13: Some Disputed Questions in the Philosophy of the Physical Sciences. By rof. E. T. Whittaker. Pp. 160-175. 18. 3d. Vol. 61, Part 2, No. 14 Pp. 176-185.9d. (Edinburgh and London: Oliver and Boyd.) [22 Pp. 176-185. 9d. (Edinburgh and London: Oliver and Boyd.) nding 31st March 1941. Pp. $19+4$ plates. (Kirkhill: Hannah Dairy Research Institute,

Mines Department. Nineteenth Annual Report of the Safety in Mine Research Board, including a Report of Matters dealt with by the Research Board, including a Report of Matters dealt with by the Health Advisory Committee, 1940. Pp. $36+3$ plates. (London:
H.M. Stationery Office.) 1s. net. Imperial Forestry Institute: University of Oxford. Seventeenth Annual Report, 1940-41. Pp. 20. (Oxford: Imperial Forestry Institute.)

\section{Other Countries}

University of Illinois Engineering Experiment Station. Bulletin No. 330: Heat Transfer to Clouds of Falling Particles. By Prof. H. F. Johnstone, Robert L. Pigford and John H. Chapin. Pp. 58 . 65 cents. Bulletin No. 331. Tests of Cylindrical Shells, a keport of an Investigation conducted by the Engineering Experiment Station University of Ininois, in co-operation with the Chicago Bridge and Iron Co. By Prof. Wibur M. Wilson and Emery D. Olson. Pp. 132. 1 dollar. Bulletin No. 332: Analyses of Skew Slabs; a Report of an Investigation conducted by the Engineering Experiment Station University of Illinois, in co-operation with the Public Roads Administration, Federal Works Agency, and the Division of Highways, Stat of Illinois. By Prof. Vernon P. Jensen. Pp. 112. 1 dollar. (Urbana. Ill. : University of Illinois Engineering Experiment Station.) [32 